FEATURE

\title{
Added Value or Essential Instruction? Librarians in the Twenty-First-Century Classroom
}

In recent years, we have seen a proliferation of the amounts of information that we're exposed to, and our ability to critically navigate that information hasn't kept pace with the speed at which it's coming at us. As information professionals we must ask ourselves - what is our role in helping students and patrons navigate information? What value can we add in a world where information is increasingly complex, contradictory, and competitive? Are our traditional methods of delivering information literacy enough? This paper looks at the evolution of information literacy instruction from the skills in the Association of College and Research Libraries (ACRL) Information Literacy Competency Standards for Higher Education (2000) through the newly adopted Framework for Information Literacy for Higher Education (2016), using examples from my own experience as a reference and teaching librarian. I will focus on how the ways in which we reach students has changed-from one-shot information literacy sessions to more in-depth interactions with students under the new Framework. I will argue, ultimately, that to truly serve students in our current information age, librarians must consider moving even deeper into the classroom, developing and teaching information literacy and critical thinking skills for credit in the college and university setting, and I will highlight a course I developed at my own institution.
How will this change what we do in the classroom?

$\mathbf{T}$ he question was posed by a colleague of mine as we stood in the kitchen preparing dinner in mid-November 2016. Our weekly gathering consists of several faculty from across disciplines, though centered in the humanities, at the University of Montana (USA), so the question was an extremely important and immediately relevant one. The occasion that prompted this question? The 2016 presidential race and the subsequent election of Donald Trump to the nation's highest office exactly one week before.

Given that our election cycle dragged on nearly two years and exposed deep racial, social, cultural, and political rifts, the question could have been-and in fact was-understood in any number of ways. It dominated the conversation for weeks, and left me at a loss. My own professional concern was that so much of the information that swirled around this election was, quite simply, incorrect. Whether it came from social media, so-called news blogs and sites, or the candidates themselves, much of what was being passed off as fact was, simply, not factual. Complex ideas were grossly simplified, ad hominem attacks
Julie Biando Edwards

Julie Biando Edwards (julie.edwards @umontana.edu) is Associate Professor, Mansfield Library, University of Montana, Missoula, Montana.

\section{A paper delivered at the} Botswana Library Association Conference, September 20-22, 2017, Francistown, Botswana.

Reference \& User Services Quarterly, vol. 57, no. 4, pp. 285-93 (c) 2018 American Library Association. All rights reserved.

Permission granted to reproduce for nonprofit, educational use. 


\section{FEATURE}

drew attention from policy discussion, and outright lies were passed in rage and righteousness around Facebook and Twitter, facilitated, as we now know, by Russian interference. Any of these issues would be of concern to teaching librarians, but at the root of my trouble, and central to the question, was the fact that I'm not, actually, in the classroom. Or, rather, I am in the classroom at the whim of others, brought in to ostensibly teach information literacy, which I do to the best of my ability in the hour per semester I'm usually with students. The space to address this central question didn't exist in the classroom. For me, there simply was no classroom.

Whereas my colleagues had dedicated time and space in which to approach difficult questions with students, I did not. Here I was, at a university, faced with questions about how information, misinformation, and disinformation affected our election, and I had no idea how to adequately approach the subject in which librarians are, theoretically, experts.

I turned over the question for weeks-how could librarians talk with students about information in new ways? What was my responsibility, as a librarian and a citizen, in the face of so much confusion? I believed in Thomas Jefferson's idea of democracy being reliant on informed citizens and had prided myself on being a member of a profession that helped create those informed citizens. I found myself wondering how I could, in the time allotted me in the classroom, tackle some of the questions about information that the election had raised. I had, over the years, become increasingly convinced that the one-shot information literacy instruction sessions were not particularly useful to students. Certainly, they were not engaging to me. Even when they were carefully integrated into the course at hand, the fifty minutes with students were mainly used to teach them where and how to locate discipline-related resources. We touched on concepts of information literacy, but not in a way that was satisfying to me and not in a way that convinced me that students actually understood information literacy as something more than library searching.

My suspicions about students' abilities to approach information with skepticism and to think critically-my own understanding of the root of information literacywere confirmed later that November. Toward the end of the month, researchers at Stanford University released a study on students' ability to evaluate information online. Their results showed that "when it comes to evaluating information that flows through social media channels, [digital natives] are easily duped."' This didn't surprise me, and in fact probably wouldn't have held my attention had it not been for their conclusion, which was startlingly frank for academic researchers: "we worry that democracy is threatened by the ease at which disinformation about civic issues is allowed to spread and flourish."2 It was this statement that ultimately convinced me that as a librarian I had a responsibility to address the questions that this election had raised. It was this that convinced me that I had to carve out a space for myself in the classroom.

\section{INFORMATION LITERACY STANDARDS IN THE CLASSROOM}

Since 2000, teaching librarians have been guided by the Association of College and Research Libraries (ACRL) Information Literacy Competency Standards for Higher Education (henceforth, Standards). These Standards were used to shape information literacy (IL) curriculum and instruction across the United States, including in my own library. The Standards defined IL as "a set of abilities" that required knowing when information was needed and having the ability to find, evaluate, and use information to address the need. ${ }^{3}$ Focusing on skills, the Standards were action-oriented-an information literate individual would determine a need, access and evaluate information, use information, and understand the complexities of information creation and use. The Standards (2000) noted that IL is cross-disciplinary and essential to lifelong learning and that it "extends learning beyond formal classroom settings and provides practice with self-directed investigations as individuals move into internships, first professional positions, and increasing responsibilities in all arenas of life.".4

Importantly, the Standards (2000) made the argument that IL ought to be embedded in and across the curriculum of colleges and universities and that the achievement of such a curriculum "requires the collaborative efforts of faculty, librarians, and administrators." At my own university, teaching librarians used the Standards to answer questions about how IL differed from information technology (IT) and to push for an IL requirement in all classes designated as "writing" (or W) courses. Instructors who wanted to teach W-courses, in making their case to the university that their courses should have a writing designation (a desirable status for any course, as students are required to take a certain number of W-courses), had to include a library instruction component in collaboration with teaching librarians or had to address IL on their own in some other way. It ensured that IL instruction was embedded across the curriculum, from first-year through graduate courses. Librarians, under the direction of our instruction coordinator, developed a curriculum and rubric that was tiered, integrated, and used to collaborate with teaching faculty in order to build embedded, course-integrated, one-shot instruction sessions. The Standards, with their skills-based emphasis, provided an easy way in which to build and measure outcomes for use in the classroom.

In theory, all students had an IL component in their first year and received additional IL instruction in their upperlevel writing classes, instruction that built on the concepts and skills learned at the lower levels. In reality, librarians wondered whether we were actually teaching transferrable skills. Some teaching faculty (though strong and often vocal supporters of the library) continued to interpret IL as "library instruction," and librarians themselves (myself included) often fell back on database searching or other such skills that could reasonably be addressed in a fifty-minute 
session. Additionally, though our curriculum was designed to augment writing classes, librarians, service-minded in a service profession, would accept teaching requests from lecturers on non-W classes who requested a session. There was a general sense that anything that got students into the library and interacting with a librarian was a good thing.

Though I loved the interaction with students and was told by teaching faculty that they could see the differences in their student papers, I was more and more convinced that I wasn't actually teaching IL. Library instruction, yes. But not IL. And while library instruction was important and indeed useful to students and faculty, I was left with the sense that the ability of students to "become engaged in using a wide variety of information sources to expand their knowledge, ask informed questions, and sharpen their critical thinking for still further self-directed learning," as the Standards promised, was not actually being achieved in the library. ${ }^{6}$ Perhaps it was, but as a librarian with classroom access to students only fifty minutes a semester and no role in evaluating or assessing student work throughout the semester, I wasn't able to determine if my time with them really did help them become more critical thinkers.

This was not a problem with the Standards themselves but with the structure in which we had implemented them. Our teaching program was strong, we were reaching many students, and we had a robust curriculum. Librarians were often inundated with teaching requests-I would teach as many as fifteen sessions a semester, across various disciplines. But the problems with the model were clear. As a liaison librarian to ten different disciplines, there was no way I could realistically be expected to be a subject expert in all of them. Teaching librarians began to talk about offering credit-based information literacy classes as opposed to teaching (or demonstrating) the resources of other disciplines. We talked for years about how we should construct a credit course, how we would get students to register for it, and how we could actually find the time to teach it, while still teaching one-shot sessions, serving as reference librarians, maintaining publication productivity, and coordinating functional areas in the library. Having taught critical thinking credit courses in the past, I was convinced that we should move away from the one-shot sessions and enter into the classroom on our own terms in order to really get to the heart of some of the critical thinking issues that were missing from our curriculum.

In some ways, our teaching was slowly moving in that direction, with the hiring of an eLearning librarian who developed video tutorials that many of us saw as far more useful to students than library instruction, as they addressed all the same topics we did and could be used at point-of-need and viewed as many times as necessary. The goal was to cut down on the one-shots by truly focusing only on the writing classes, to retool the instruction in these classes away from demonstrations (which were now covered by the tutorials) and toward analysis of information, and to free up time to truly think about developing credit courses.

\section{FROM STANDARDS TO FRAMES}

Whether we wanted to change the way we were doing instruction or not ultimately didn't matter. In June 2016, the ACRL retired the Standards. In their place was the new Framework for Information Literacy for Higher Education (henceforth, the Framework), which had been approved as an updated set of guidelines for IL instruction in January of that year. The adoption of the Framework, which noted that "information literacy as an educational reform movement will realize its potential only through a richer, more complex set of core ideas," as a replacement for the Standards provided us additional professional context in which to discuss IL in practice. ${ }^{7}$ Most notably, the Framework moves away from skills and toward concepts. Key to the Framework are conceptual understandings that organize many other concepts and ideas about information, research, and scholarship into a coherent whole. These conceptual understandings are informed by the work of Wiggins and McTighe, which focuses on essential concepts and questions in developing curricula, and also by threshold concepts, which are those ideas in any discipline that are passageways or portals to enlarged understanding or ways of thinking and practicing within that discipline. ${ }^{8}$

A threshold concept, which ACRL borrowed from other disciplines, is:

1. transformative, in that it changes the way a learner approaches a field;

2. irreversible, in that it cannot be unlearned once learned;

3. integrative, in that it exposes connections between ideas that previously seemed unrelated;

4. bounded, in that it is particular to a specific field;

5. and troublesome, in that it is somehow challenging to students.

Kuglitsch notes that these characteristics are descriptive, not definitional; "in other words, they are not required qualities that must be checked off to qualify an idea as a threshold concept. ... A threshold concept need not be a full, identical match for the five characteristics but rather should have a general fit with most of them."

Rather than focusing primarily on skills, as the Standards had, the Framework focuses on "knowledge practices, which are demonstrations of ways in which learners can increase their understanding of these information literacy concepts, and dispositions, which describe ways in which to address the affective, attitudinal, or valuing dimension of learning." ${ }^{10}$ The Framework is divided into six frames that illustrate central IL concepts and are supported throughout the document with relevant knowledge practices and dispositions:

- Authority Is Constructed and Contextual

- Information Creation as a Process

- Information Has Value

- Research as Inquiry 


\section{FEATURE}

- Scholarship as Conversation

- Searching as Strategic Exploration

The Framework is a departure from the Standards, and one not without controversy. One of the core complaints is that, while the concepts should provide for "flexible options for implementation," librarians struggled with how to implement them in practice. ${ }^{11}$ Since the draft release of the Framework in 2015, librarians have written about the changes and challenges they present, with some highlighting the potential for new ways of teaching and learning, and others noting that the amount of work it will take for librarians to adjust teaching curriculum is impractical, especially given the fact that the Framework does not provide concrete examples of how to adjust curriculum, never mind how to actually implement the frames in a classroom. ${ }^{12}$ Bombaro observes that discussions about the Framework divided librarians into roughly two camps, those with "advanced degrees along with the benefits often associated with large institutions, including faculty status" and those "who may not have had terminal degrees or any other advanced degree besides a master's in library science" and without "faculty equivalence."13

The librarians at my institution fall into Bombaro's first category, and by March 2016, internal library e-mails indicated that there was general agreement that "the new ACRL Framework [that had been filed in draft form in 2015] supports a move away from class-integrated teaching." At that point, we had been discussing how to redesign our instruction program for three full years. I, for one, appreciated the opportunity that the complexity of the Framework might provide for developing credit-bearing IL classes. Scott points out that the "co-authors of the Framework ... advocate redesigning courses to accommodate its 'set of "big ideas" about research, scholarship, and information,"'14 while Mays notes that "traditional, one-shot instruction sessions that focus on search skills in periodical databases and catalogs are no longer adequate to support either ACRL's new framework or the sophisticated skills needed in today's workforce."15 I saw no way in which we could maintain our one-shot sessions within the Framework. Unfortunately, shrinking budgets and a loss of library staff meant that librarians were taking on more and more work. Few of us had time to develop a credit class, and there were legitimate concerns about the scalability of such a class, as well as concerns about how many students we might not reach if we stepped fully away from one-shots. Our compromise was to redesign the curriculum in light of the Framework and to formally and exclusively focus on upper-level writing courses, providing information about the frames and a "menu" that faculty could use to select which frame they wanted addressed in their classes. Librarians then shared teaching strategies and lesson plans with each other so that we could have a bank of instruction material and knowledge from which we could draw to teach the frames in discipline specific ways.

In my own experience with this new model, one-shot sessions became more complex and more satisfying; anecdotal and official feedback from students and faculty indicated the same. Most of the faculty with whom I worked wanted to focus on the frame of Authority. The concept of constructed and contextual authority works well in many of the departments and programs for which I am a liaison, as they are largely interdisciplinary and focus on gender, ethnic, or area studies. I approached this frame by providing students readings from their own disciplines before class, which we then used class time to dissect-questioning whose authority was represented in the text, how that related to the larger world of academia, whose voices might be missing, and how students in their own research might bring in those missing voices. While I enjoyed talking about the frames in the context of their disciplines, though, it was difficult to determine if we were really addressing threshold concepts. Kuglitsch notes that the disciplinary nature of threshold concepts is not one that fits easily into IL, as IL "is a field that extends across other fields." ${ }^{.16}$ In this way, I still had questions about whether or not I was actually teaching information literacy, though I felt that I was getting closer to it. At the very least, I did feel as though the Framework provided me with more robust ways to interact with upper-level students in the classroom.

\section{CARVING OUT SPACE IN THE CLASSROOM}

While we were adjusting our IL curriculum to more closely align with the Framework, I was carving out my own space in the classroom in response to the question raised by my colleagues and the Stanford study. Before delving into the details of my own course development though, it is worth looking at the ways in which librarians have attempted to address IL in credit courses.

Credit-bearing IL courses are not new. Librarians have been teaching them and writing about them for years. More than a decade ago Hrycaj reviewed online syllabi for creditbearing library skills courses, research that Elrod, Wallace, and Sirigos built on as they looked at credit-bearing information literacy courses. ${ }^{17}$ Some researchers have pointed out that "student information literacy skills are incomplete when information literacy is reduced to one class." ${ }^{18}$ Burke looked at the practical considerations that credit-course teachers must consider, including questions of assessment, retention, and delivery method..$^{19}$ On the question of course delivery, some researchers looked at web-based models of IL credit-courses as a way of meeting student needs outside of a formal classroom setting. ${ }^{20}$

One popular model seems to be the integration of IL credit-courses into other disciplines. Faust described the teaching of an IL course as part of a general education program that combined students into subject clusters, though she found that one of the challenges of teaching IL, even in a credit-course, is that students have difficulty understanding IL as something that is useful beyond researching for papers-something that librarians themselves had trouble communicating to them. ${ }^{21}$ Researchers have also pointed 
out the benefits of a deeply embedded IL course in the discipline and have advocated for general education IL classes as a way to approach questions of critical information literacy that embrace political, cultural, and social contexts. ${ }^{22}$ Some have argued persuasively that hybrid models that encourage IL credit-courses while maintaining the one-shot instruction sessions have potential, ${ }^{23}$ though Davis, Lundstrom, and Martin note that "the majority of librarians who teach using both models appear to favor for-credit [classes]. ${ }^{24}$ As the Framework has come to replace the Standards, more recent scholarship has looked at the ways in which they will change the way we teach and has examined how students understand the frames in order to consider the best ways to integrate them into the classroom. ${ }^{25}$

Stepping slightly away from strict IL credit-courses, Kemp looked at the potential of librarians teaching non-IL courses finding that, despite some drawbacks, the benefits of "closer interaction with students over an extended period of time, a deeper understanding of faculty workloads, student needs, and administrative requirements, news ways of looking at collection development, enhancement of faculty status, increased intellectual stimulation, and sharper selfassessment of performance" all "argue that librarians should teach credit-bearing courses when possible." 26 She points out that "students will be more comfortable about visiting the library" and will "learn to use the library" as a result of "deeper relationships with a librarian" and that faculty status for academic librarians "is validated" when they are in the classroom as teachers. ${ }^{27}$ She returns to the question of whether librarians have a discipline - a position I and others in my library have advocated as we consider whether librarians can and should teach credit-classes - by noting that "if academic librarians view the profession as a discipline, then it follows that the same librarians may more readily embrace the faculty responsibilities of teaching and scholarship" and "teaching in their own discipline." ${ }^{28}$

\section{IL BY ANY OTHER NAME}

Teaching the discipline was in the forefront of my mind in November 2016. As I considered the question of the classroom posed by my colleague and turned over the troubling results of the Stanford study in my mind, I was convinced that I needed to be in the classroom in a more formal way. The Stanford study findings rattled my conception of teaching IL, though. I began to question whether the focus on finding, evaluating, and integrating information into student questions was perhaps a step beyond where we should be starting. The Stanford findings, indicating that students couldn't critically approach everyday material in the real world, made me wonder if a strictly academic application of IL, even in a credit-class, was missing an opportunity to really teach students transferable critical thinking skills. If students couldn't determine when a digital photo had been altered, or when content in their social media feeds was

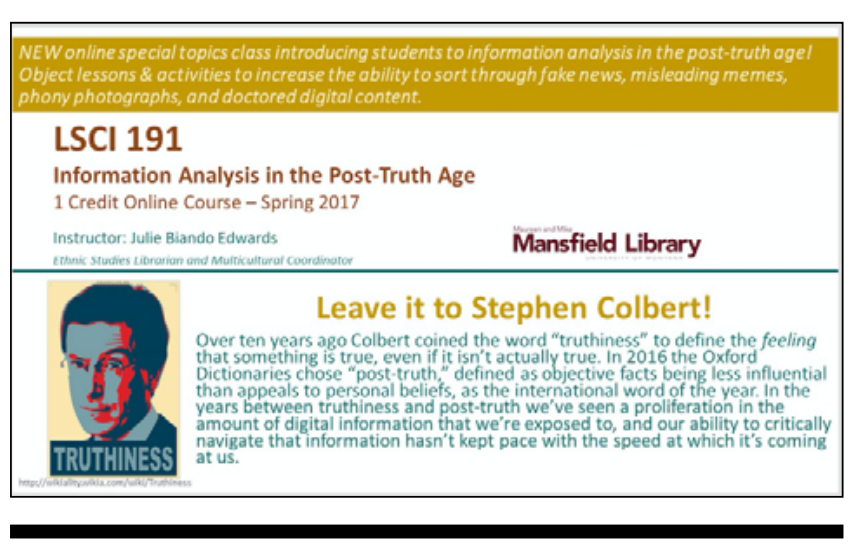

Figure 1. Flier for the class, designed by Patti McKenzie, Mansfield Library.

actually an advertisement, or when a website was full of suspect content, should I really be focusing on teaching them IL in relation to the library or their disciplines? When so many people had made decisions about their most important civic duty (voting) based on false information, was the best use of my classroom time spent on the traditional questions of IL? Could the core principles of IL_critical and skeptical analysis of information-be taught without calling it IL? I decided to try. In the few weeks between the end of November and the end of the fall semester in mid-December, I got a course number and description for a one-credit critical thinking/IL course. The course was offered online because by that point in the semester many students were fully registered for spring classes and I reasoned that few would want to add another course that might conflict with their schedules. Drawing on the Oxford Dictionaries' Word of the Year, Information Analysis in the Post-Truth Age (see figure 1) was born, and eight students enrolled.

I looked at some of the main issues presented in the Stanford study and built the course around that, focusing on material that students would encounter online and particularly in their social media environments. Each week was dedicated to a topic (see figure 2): clickbait, like-farming, misleading memes and images, sponsored content, and fake news. We also looked at more conceptual topics such as understanding satire, the differences between facts and opinions, the use of emotions in spreading fake news, evaluating sources for authority and credentials, and looking at the differences between bias and credibility. One week was spent on looking at the IMVAIN method of information analysis. ${ }^{29}$ Other lessons focused on how to manage breaking news and how to approach science and health headlines with skepticism, largely supported with the excellent podcasts from On the Media. ${ }^{30}$ I focused strictly on using non-academic sources for the course, including videos, websites, blogs, newspapers, magazines, and podcasts for course material.

My goal was to have students as deeply embedded in the online media environment as possible. The course was asynchronous, and students used Moodle to access course materials and submit their weekly assignments, which asked 


\section{FEATURE}

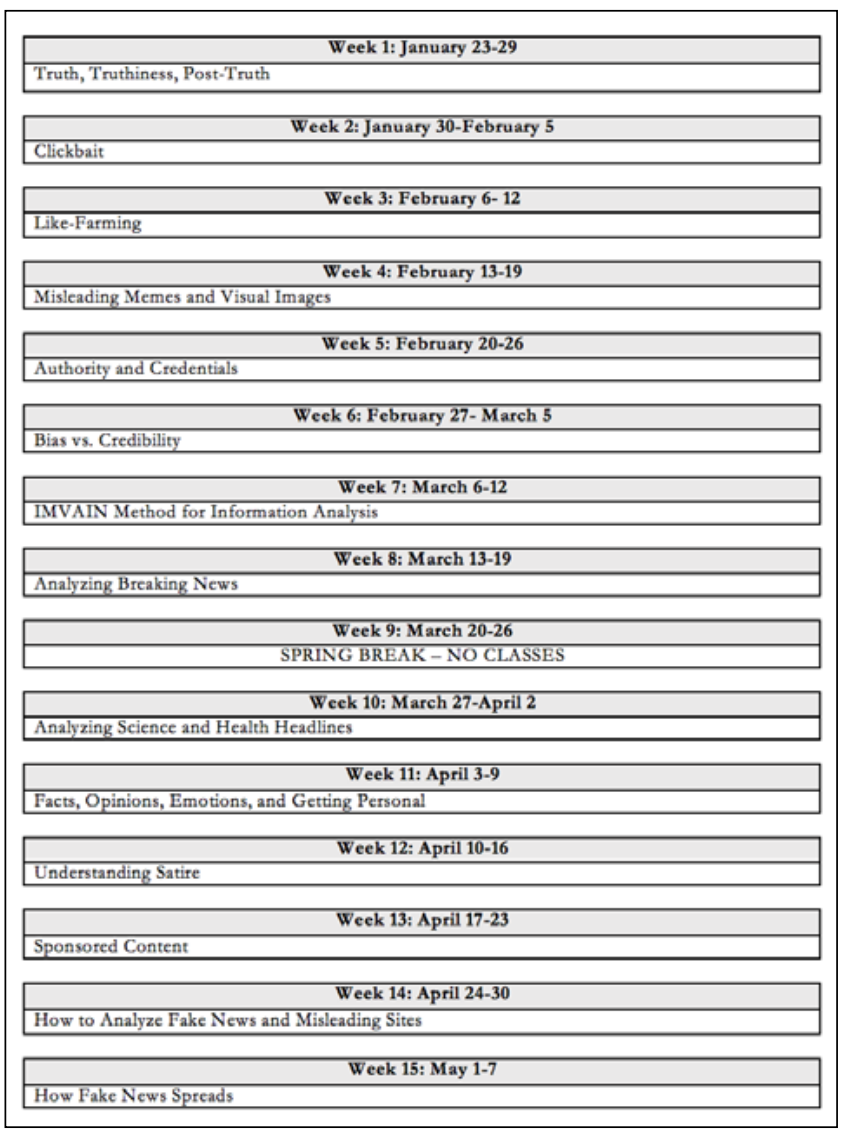

Figure 2. Course outline, LSCI 191.

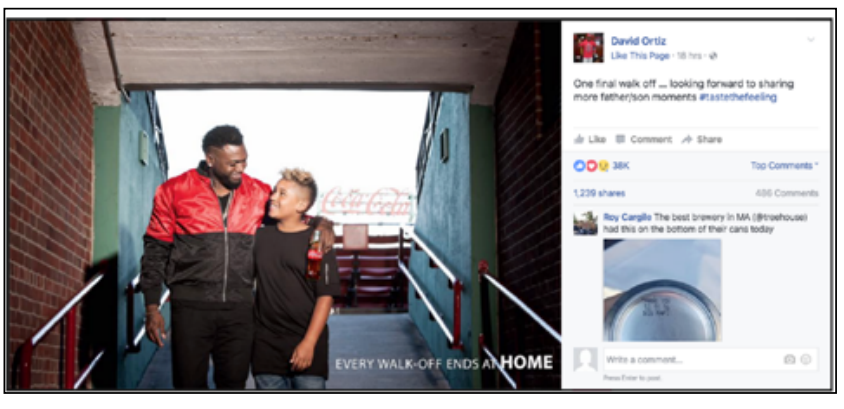

Figure 3. A screenshot of David Ortiz's Facebook page. We used real-world social media like this to discuss topics such as sponsored content. Original image and analysis at https://www .truthinadvertising.org/ad-not-big-papis-final-walk-off/.

them to think critically and apply the lessons of each week, often asking them to scour their own social media feeds looking for sponsored content, clickbait, and ad hominem arguments or emotional appeals, for example (see figures 3-5).

I did consult the Framework in developing the course, particularly the frame on authority. This frame greatly influenced my lesson on authority and credentials, which involved students critically analyzing a video on the anti-vaccine movement in the United States to look at the different

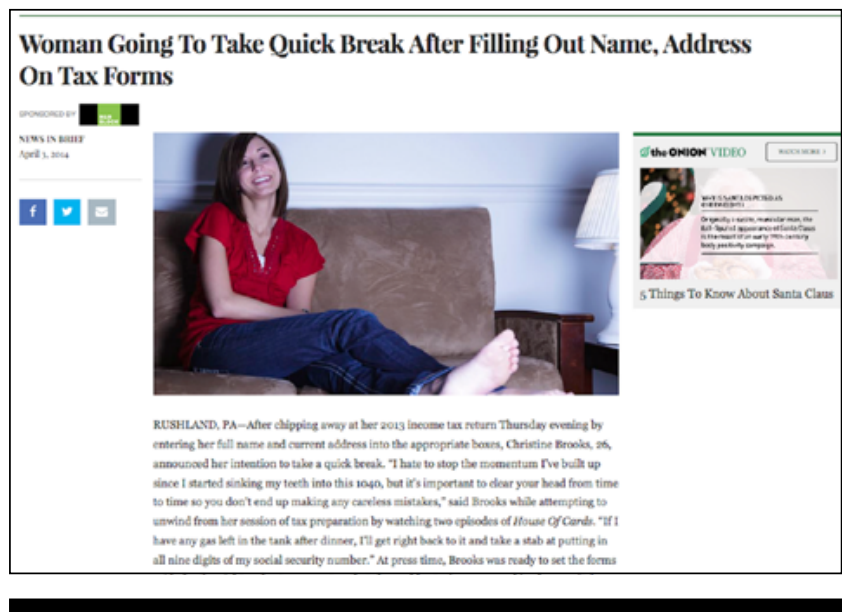

Figure 4. This screenshot from the satirical site The Onion highlights the complexity of the online environment: this particular "article" is both satire and sponsored content. Original image at https://www.theonion.com/woman-going-to-take-quick-break -after-filling-out-name-1819576310.

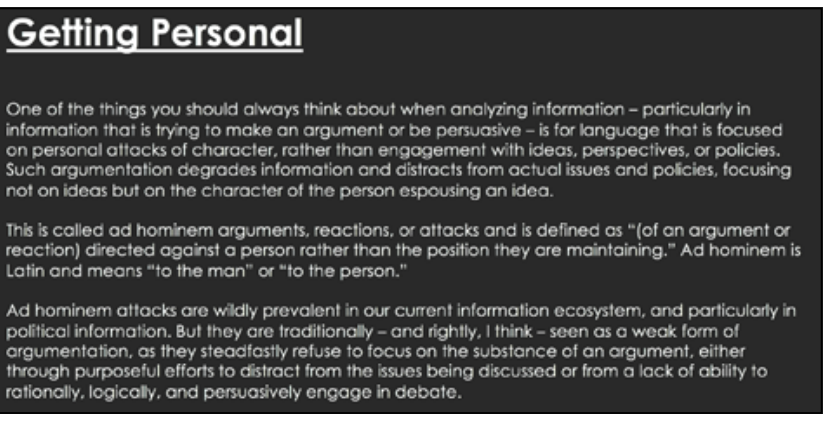

Figure 5. A screenshot from one of the weekly lesson slides, which I voice recorded for students with visual disabilities.

ways in which authority is constructed and credentials valued by both pro- and anti-vaccine advocates. Other frames, such as the frame Information Has Value, came into play less explicitly when we addressed topics such as sponsored content and native advertising.

In constructing and teaching the course I worried that these skills and this level of analysis were painfully below where we should be teaching at a university. Rereading the Stanford study set some of those fears aside, as did the response from colleagues at my university who, when I sent them the course to advertise it with their students, responded with unabashed enthusiasm. Clearly these were skills that were not being addressed elsewhere in the curriculum. Students themselves seemed excited about the material and would note that they were learning new ways of evaluating information. A pre-test given in the first week of class indicated that some topics, such as sponsored content, were indeed fairly new to students. The pre-test was designed to give me an idea of what students might already know and to get them thinking about what they might already know. I wanted them to think not only about their 
online environment but about where they get information about topics that interest them on a daily basis. The pre-test (figure 6) tried to cover several of the major topics that would be covered in the course and, even in cases where students provided the "correct" answers, I tried to use these answers to determine exactly how deep their knowledge ran.

Final exam questions built on these pre-test questions and asked for some of the same information in more depth. For example, some of the final exam questions included: Define the five characteristics of clickbait, how they work, and provide an example for each; what is like-farming and how does it work?; what is the difference between an expert and an authority?; and what is sponsored content, what is it used for, and what are seven ways you can look out for it?

The class went well, though students struggled with the anti-vaccine video in particular, focusing too much energy on the substance of the arguments and whether they agreed with them or not rather than looking at the ways in which authority is developed, claimed, or shifted. My weekly assignments (see figures 7-10), though they seemed straightforward and undemanding to me, caused some consternation from students who thought that I was demanding too much.

A significant drawback from my perspective is the fact that we were not in a face-to-face course. In my rush to get the course on the books (never mind designing it, finding readings, building assignments, and setting it up in Moodle), I felt I had to offer it online because students had already selected and registered for their Spring courses. Offering it face-to-face would mean that it would likely clash with already enrolled courses, whereas as an asynchronous online course, students could complete the work at any time. While the benefits of this allowed me to easily manage assignments and know when students were doing the reading, the things that I most love about teaching (and that would have been most useful in this class), such as discussion and debate, were lost. I regularly (weekly) kept in touch with students via e-mail, but that wasn't a replacement for the richness of being in a shared classroom. At the end of the semester, though, I was satisfied and energized at having been able to address topics of information analysis in the classroom. The student evaluations I received seemed to indicate that at least some students found the class engaging and useful as well.

\section{OBSERVATIONS AND THOUGHTS ABOUT THE FUTURE}

Were this class offered again (I was on sabbatical the following semester and didn't teach it), I would redesign it as a face-to-face class, increase the credit load to three credits, and work in more basic writing skills, an area in which almost all of the students struggled. I'd pay more attention to the other frames in order to integrate the concepts more fully into the class and would more explicitly draw on them to support teaching and learning. I would also address the
This is graded only on participation - not on whether your answers are correct or not! You will get full credit just for turning this in. If you don't know an answer, it is completely fine to say "I don't know." I want to see what you know about some of the topics we're going to talk about this semester. Don't spend time looking up answers you don't know-just move through the questions to the best of your knowledge.

1. What does post-truth mean?

2. How do you typically get information about something you're interested in? Books? Social media? Websites? Search engines? Friends? Family? Others?

3. What is fake news?

4. What is clickbait?

5. What is like-farming?

6. What makes someone an expert?

7. What is bias?

8. What is sponsored content?

9. Are people more likely to share news that makes them happy or makes them angry?

10. This is a fake news headline, true or false: "Obama Signs Executive Order Banning The Pledge Of Allegiance In Schools Nationwide."

11. This is a fake news headline, true or false: "At West Point, Annual Pillow Fight Becomes Weaponized."

Figure 6. Pre-test.

shifting environment of online influence we have seen in the past year or so. Ideally a course like this would be offered as part of the general education curriculum, perhaps with a writing designation, in an effort to reach more students. I do think that, should enrollment ever grow to a point where the course could not be taught in a traditional classroom, it could continue to be taught as an online course.

One of the things that I would not change is the name and the focus-teaching critical thinking concepts (or IL, for that matter) doesn't have to be done through classes called Introduction to Critical Thinking. If we're competing for student attention as they decide on a vast array of courses, we need to stoke their interest.

As the Stanford study results illustrate, we're assuming that students are coming into our IL or critical thinking classes with some level of basic ability to analyze content that is, sadly, lacking. The rate at which information is created and shared, and the increasing sophistication with which it is produced and packaged, combined with the online bubbles created by an increasingly partisan and hostile readership influenced by outside actors, seems to have limited students' ability to be skeptical about what they're encountering online. Courses that teach students some skills in approaching material critically may have a benefit as they move into more traditionally academic focused courses. I certainly hope it will have a benefit as students consider 


\section{FEATURE}

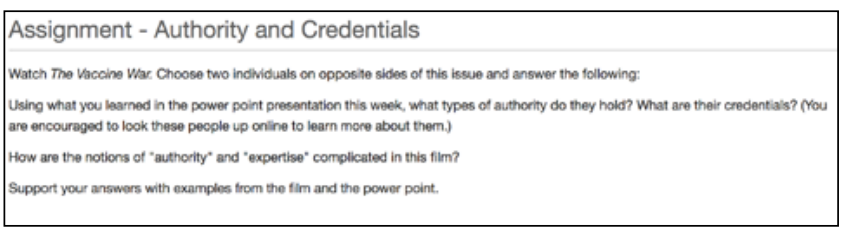

Figure 7. Weekly assignment on analyzing authority and credentials.

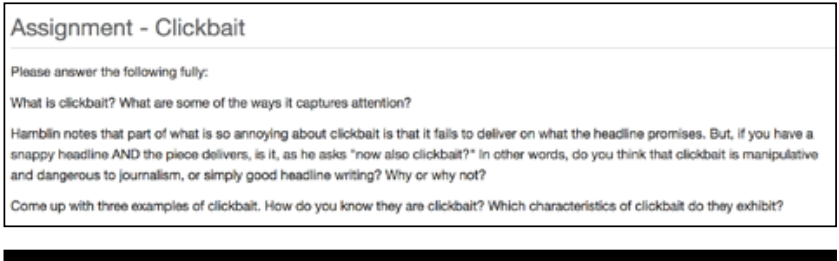

Figure 8. Weekly assignment on clickbait.

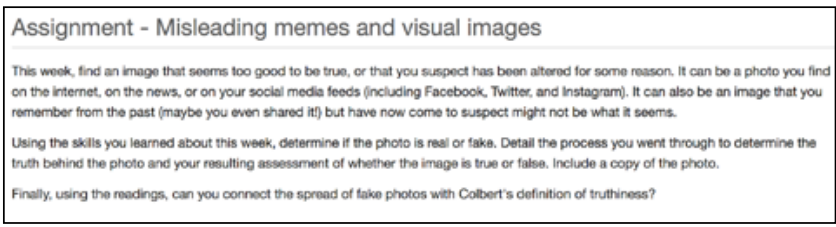

Figure 9. Weekly assignment on memes and altered images. Note that I wanted students to investigate their own social media feeds and behavior.

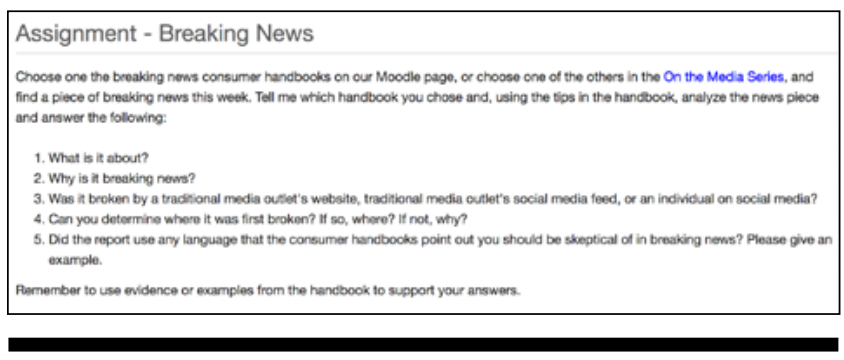

Figure 10. Weekly assignment on breaking news.

their role as consumers of media and citizens of a democracy.

Should librarians be in the classroom? I believe they should. My own experience in the classroom always engages me and I see the benefits that Kemp pointed out over a decade ago in her own analysis of librarians in the classroom. ${ }^{31} \mathrm{I}$ am more engaged as a librarian when I am also engaged as a teacher. Beyond personal satisfaction though, and beyond the value that librarians teaching IL add to higher education, we're seeing a real need for basic critical thinking skills that students are not currently receiving. The Stanford study and the responses from faculty colleagues both attest to this. Librarians can be involved in essential instruction at the university level, reaching students in ways that incorporate information literacy and critical thinking. This instruction would be outside of the disciplines, but it is no less important-in fact one could argue that in a democracy it is more important- than the teaching of traditional IL in a disciplinary context. It appears that right now very few students are learning to approach information skeptically. Who better to teach this than librarians? Were we to revise our instruction models in a way that would make them more engaging for librarians and more useful for students in both an academic and practical sense, we could illustrate our value on campus in new ways. This model doesn't throw out one-shot sessions or traditional IL credit-courses, but it does argue for a more basic though no less important approach to meeting very real gaps in students' critical thinking skills. Further research is necessary to determine the feasibility and impact such a change instruction would have at the tertiary level but, in the meantime, librarians who want to develop credit-courses such as this should be encouraged to do so as a way to demonstrate value, provide essential instruction, and change what they're doing in the classroom.

\section{References}

1. Stanford History Research Group, Executive Summary: Evaluating Information: The Cornerstone of Civic Online Reasoning, (Stanford, CA: Stanford University, 2017), 4, https://stacks .stanford.edu/file/druid:fv75lyt5934/SHEG\%20Evaluating\%20 Information\%20Online.pdf.

2. Stanford History Research Group, Executive Summary: Evaluating Information, 5.

3. Information Literacy Competency Standards for Higher Education, Association of College and Research Libraries (Chicago: American Library Association, approved January 18, 2000), 2, https://alair.ala.org/handle/11213/7668 (hereafter cited as Standards)

4. Standards, 4

5. Standards, 4

6. Standards, 5

7. Framework for Information Literacy for Higher Education, Association of College and Research Libraries (Chicago: American Library Association, adopted January 16, 2016), 2, http://www.ala .org/acrl/standards/ilframework (hereafter cited as Framework).

8. Framework, 2.

9. Rebecca Z. Kuglitsch, "Teaching for Transfer: Reconciling the Framework with Disciplinary Information Literacy," portal: Libraries and the Academy 15, no. 3 (2015): 459, https://doi .org/10.1353/pla.2015.0040.

10. Framework, 2.

11. Framework, 2.

12. For notes on adapting the Framework for teaching, see Kuglitsch, "Teaching for Transfer"; Colleen Burgess, "Teaching Students, Not Standards: The New ACRL Information Literacy Framework and Threshold Crossings for Instructors," Partnership: The Canadian Journal of Library and Information Practice and Research 10, no. 1 (2015): 1-6, https://doi.org/10.21083/partnership. vl0i1.3440; Allison Fullard, "Using the ACRL Framework for Information Literacy to Foster Teaching and Learning Partnerships," South Africa Journal of Libraries \& Information Science 82, no. 2 (2016): 46-56, https://doi.org/10.7553/82-2-1627; Rachel Scott, "Part 2. If We Frame It, They Will Respond: Student Responses to the Framework for Information Literacy for Higher Education," The Reference Librarian 58, no. 1 (2017): 19-32, doi: https://doi.org/10.1080/02763877.2016.1196471. For a critique of implementing the Framework, see Christine Bombaro, "The Framework Is Elitist," Reference Services Review 44, no. 4 (2016): 552-63, https://doi.org/10.1108/RSR-08-2016-0052. 
13. Bombaro, "The Framework Is Elitist," 555-56.

14. Scott, "If We Frame It," 20.

15. Dorothy A. Mays, "Using ACRL's Framework to Support the Evolving Needs of Today's College Students," College \& Undergraduate Libraries 23, no. 4 (2016): 356, https://doi.org/10.1080 /10691316.2015.1068720.

16. Kuglitsch, "Teaching for Transfer," 459.

17. Paul L. Hrycaj, "An Analysis of Online Syllabi for Credit-Bearing Library Skills Courses," College \& Research Libraries 67, no. 6 (2016): 535; Rachael E. Elrod, Elise D. Wallace, and Cecelia B. Sirigos, "Teaching Information Literacy: A Review of 100 Syllabi," The Southeastern Librarian 60, no. 3 (2012): 8-15, http:// digitalcommons.kennesaw.edu/seln/vol60/iss3/4.

18. Mimi O'Malley, "Information Literacy Grown Up: One-Shot Instruction to Credit-Bearing Course," Kentucky Libraries 73, no. 4 (2009): 16.

19. Margaret Burke, "Academic Libraries and the Credit-Bearing Class: A Practical Approach," Communications in Information Literacy 5, no. 2 (2012): 156-73, eduscapes.com/instruction /articles/burke.pdf

20. Vilve Seiler, Kärt Miil, and Krista Lepik, "How to Fit Teaching of Information Literacy in with Students' Needs: An On-line Credit Course Model from the University of Tartu Library," Liber Quarterly 22, no. 1 (2012): 42-63, https://www.liberquarterly .eu/articles/10.18352/lq.8040/.

21. Judith Faust, "Teaching Information Literacy in 50 Minutes a Week: The CSUH Experience," Journal of Southern Academic and Special Librarianship 21, no. 3 (2001), http://southernlibrarian ship.icaap.org/content/v02n03/faust_j01.htm.

22. Carol A. Powell and Emily C. Ginier, "Lessons Learned: Yearby-Year Improvement of a Required Information Competency Course," Medical Reference Services Quarterly 32, no. 3 (2013):
290-313, https://doi.org/10.1080/02763869.2013.806862; Ian Beilin and Anne E. Leonard, "Teaching the Skills to Question: A Credit-Course Approach to Critical Information Literacy," in "Libraries, Information, and the Right to the City: Proceedings of the 2013 LACUNY Institute," special issue, Urban Library Journal 19, no. 1 (2013): 1-10, http://academicworks.cuny.edu /ulj/voll9/issl/10.

23. Erin L. Davis, Kacy Lundstrom, and Pamela N. Martin, "Librarian Perceptions and Information Literacy Models," Reference Services Review 39, no. 4 (2011): 686-702, https://doi .org/10.1108/00907321111186695; Jennifer Mayer and Melissa Bowles-Terry, "Engagement and Assessment in a Credit-Bearing Information Literacy Course," Reference Services Review 41, no. 1 (2013): 62-79, https://doi.org/10.1108/00907321311300884.

24. Davis, Lundstrom, and Martin, "Librarian Perceptions," 697.

25. Susan Ariew, "How We Got Here: A Historical Look at the Academic Teaching Library and the Role of the Teaching Librarian," Communications in Information Literacy 8, no. 2 (2014): 208-24, http://www.comminfolit.org/index.php?journal=cil\&page=artic le\&op=view\&path\%5B\%5D=v8i2p208; Burgess, "Teaching Students," 1-6; Scott, "If We Frame It," 20.

26. Jane Kemp, "Isn't Being a Librarian Enough?," College \& Undergraduate Libraries 13, no. 3 (2006): 5, https://doi.org/10.1300 /J106v13n03_02.

27. Ibid., 11.

28. Ibid., 21 .

29. "Introducing IMVAIN," Center for News Literacy, accessed February 22, 2018, http://drc.centerfornewsliteracy.org/content /introducing-imvain.

30. "All Topics," On the Media, accessed February 22, 2018, https:// www.wnyc.org/topics.

31. Kemp, "Isn't Being a Librarian Enough?," 3-23. 